\title{
The legacy of man-made organic compounds in surface sediments of Pina Sound and Suape Estuary, northeastern Brazil
}

\author{
Gilvan Takeshi Yogui ${ }^{1 *}$, Satie Taniguchi², Josilene da Silva², Daniele de Almeida Mirandal, \\ Rosalinda Carmela Montone ${ }^{2}$
}

\author{
${ }^{1}$ Departamento de Oceanografia da Universidade Federal de Pernambuco \\ (Av. Arquitetura s/n, Recife, PE, 50740-550 - Brazil) \\ ${ }^{2}$ Instituto Oceanográfico da Universidade de São Paulo \\ (Praça do Oceanográfico, 191 - São Paulo - SP - 05508-120 - Brazil) \\ *Corresponding author: gilvan.yogui@ufpe.br
}

\section{Abstract}

Polychlorinated biphenyls (PCBs) and organochlorine pesticides (OCPs) are man-made organic chemicals that have adverse effects on aquatic organisms, sometimes altering ecosystem functioning with potential consequences for the coastal carbon cycle. This study assessed PCBs and OCPs in surface sediments of two estuaries with distinct historical land use on the coast of Pernambuco, northeastern Brazil. OCPs such as HCB, aldrin, dieldrin, isodrin, mirex, methoxychlor, endosulfans ( $\alpha$ - and $\beta$-isomers), HCHs $(\alpha-, \beta-, \gamma$ - and $\delta$-isomers) and chlordane-related compounds were below their respective limits of detection in all samples. Mean levels of PCBs in Pina Sound and Suape Estuary were 4.37 and 0.94 $\mathrm{ng} \mathrm{g}^{-1}$ dry weight (dw), respectively. Average concentrations of DDTs in those same estuaries were 5.24 and $0.42 \mathrm{ng} \mathrm{g}^{-1} \mathrm{dw}$, respectively. No significant correlations were found between mud and contaminants (either PCBs or DDTs) at Pina Sound. In contrast, PCBs were significantly associated with mud at Suape Estuary. The greater contamination found at Pina Sound is consistent with land use of the urban, densely populated city of Recife. Residues of DDTs found in sediments of both estuaries reflect past local usage. Occasional adverse biological effects may be expected due to the levels of DDTs at several sites in Pina Sound. Lower levels of chemicals such as PCBs in the newly industrialized Suape Estuary suggest that a similarly low impact of legacy pollutants may be expected for future industrial enterprises around the world.

Descriptors: Pollution, Persistent organic pollutant, PCB, DDT, Sediment quality guideline, Pernambuco.

\section{Resumo}

Bifenilas policloradas (PCBs) e pesticidas organoclorados (OCPs) são compostos orgânicos sintéticos que causam efeitos negativos em organismos aquáticos, eventualmente alterando o funcionamento de ecossistemas com consequências locais para o ciclo do carbono. O presente estudo investigou PCBs e OCPs em sedimentos superficiais de dois estuários com distintos históricos de ocupação na costa de Pernambuco. Os pesticidas HCB, aldrin, dieldrin, isodrin, mirex, metoxicloro, endosulfans, $\mathrm{HCHs}$ e clordanos não foram encontrados acima de seus limites de detecção nas amostras. As concentrações médias de PCBs na Bacia do Pina e no Estuário de Suape foram 4,37 e 0,94 ng g-1 peso seco (ps), respectivamente. Para DDTs, as concentrações médias nesses estuários foram

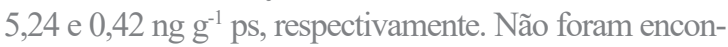
tradas correlações significativas entre a fração lamosa do sedimento e os contaminantes (PCBs e DDTs) na Bacia do Pina. Em contrapartida, os PCBs foram encontrados associados à lama no Estuário de Suape. A maior contaminação na Bacia do Pina é condizente com a área historicamente urbanizada e densamente povoada da cidade do Recife. A composição de DDTs no sedimento de ambos os estuários indica uso antigo desse pesticida. Os níveis de DDTs em diversos pontos da Bacia do Pina podem ocasionalmente desencadear efeitos negativos na biota local. Por outro lado, os baixos níveis de PCBs encontrados no Estuário de Suape - uma área que passa por recente processo de industrialização - sugerem que novos complexos industriais tendem a causar baixo impacto em termos de poluentes orgânicos persistentes herdados de práticas antigas.

Descritores: Poluição, Poluente Orgânico Persistente, PCB, DDT, Diretriz de qualidade de sedimentos, Pernambuco.

Submitted on: $21 /$ June/2017

Approved on: 26/January/2018

http://dx.doi.org/10.1590/S1679-87592018148206601 


\section{INTRODUCTION}

The transport of carbon across the continent-ocean interface has been recently recognized as a major component of the global carbon cycle (Ciais et al., 2013). In spite of their importance, the complex interactions between carbon sources, sinks and cycling in coastal environments remain poorly understood (Bauer et al., 2013). Estuaries are transitional aquatic systems that have been historically used for human settlement. They play an important role as geochemical barriers, retaining and metabolizing organic matter prior to its export into the coastal ocean (Canuel et al., 2012). Some anthropogenic organic chemicals constitute a source of toxic carbon compounds for living organisms since they may cause impairment from organelles to ecosystems. Despite being quantitatively unimportant for the carbon budget in estuaries, such chemicals may indirectly affect the local carbon cycle through modification of ecosystem functioning.

Persistent organic pollutants (POPs) are man-made chemicals slowly metabolized in the environment. They are of lipophilic nature, accumulate in biological tissues and undergo biomagnification in the food web. In addition, POPs are a potential cause of adverse effects on living organisms, including the man. Polychlorinated biphenyls (PCBs) and organochlorine pesticides (OCPs) are POPs of major concern since their environmental half-lives may be over a decade and they were extensively used in Brazil (Sericano et al., 2014; Almeida et al., 2007). The Brazilian government prohibited the industrial use of PCB in 1981 although equipments containing PCBs were allowed to remain on the market until the end of their lifetimes (Penteado and Vaz, 2001). Legal use of OCPs in agriculture was phased out in the 1980s, and their use was prohibited in 1998 for public health purposes (Yogui et al., 2010). Despite their phase-out, PCBs and OCPs are still found in several environmental matrices along the Brazilian coast (e.g., Bícego et al., 2006; Fillmann et al., 2007; Miranda and Yogui, 2016; Oliveira et al., 2016).

The state of Pernambuco is located on the northeastern coast of Brazil. It has the most densely populated coastal zone among all the Brazilian states, with over 900 inhabitants per square kilometer (Moraes, 2007; Barbosa et al., 2008). Recife is the largest city on the coast of Pernambuco, with 1.6 million inhabitants (IBGE, 2016). The Capibaribe River estuary flows through Recife, receiving high loads of untreated wastewater runoff from the metropolitan area (Schettini et al., 2016). This has compromised water quality in recent decades, turning the estuarine waters from eutrophic to hypereutrophic
(Nascimento et al., 2003; Paranaguá et al., 2005; Flores Montes et al., 2011). Recently, the pressure of economic growth has led to the construction of an industrial complex along with the expansion of a commercial port in the vicinity of Suape Estuary where rapid industrialization has occurred in the past decade and about 100 companies are currently established (Lemos et al., 2014).

There is no official inventory on the use of organochlorine compounds in the state of Pernambuco. Major potential local sources of PCBs are old power transformers. Former agricultural practices and public health campaigns for combating tropical disease vectors such as malaria and dengue fever are potential local sources for OCPs. It is noteworthy that illegal use of OCPs (e.g., aldrin, dieldrin, mirex) has been recorded in agricultural practices in the state of Pernambuco in the 1990s (i.e., after the Brazilian phase-out) (Araújo et al., 2000).

Few studies have addressed POP pollution along the coast of Pernambuco, and none of them has investigated sediment contamination (Sericano et al., 1995; Miranda and Yogui, 2016; Anzolin et al., 2012). This is the first assessment of PCBs and OCPs in estuarine sediments of Pina Sound and Suape Estuary, northeastern Brazil. Concentrations and contaminant profiles of the two estuaries are compared, including their possible connections with historical land use and pollutant phase-out. Local sediment contamination is also compared with that of several other coastal environments around the world. Finally, the potential risks of adverse biological effects are evaluated using different sediment quality guideline approaches.

\section{MATERIAL AND METHODS}

\section{STUDY AREA}

The southern part of the Capibaribe estuary is a shallow, wide body of water known as Pina Sound (Figure 1). It is formed by the confluence of four streams: the southern branch of the Capibaribe River, Tejipió Creek, Jordão Creek, and Pina Creek. This last one is a tidal creek consisting of three narrow channels that flood the largest urban mangrove area in Brazil (Farrapeira, 2006). Jordão and Tejipió are small coastal creeks which rise in the Recife metropolitan area. Jordão Creek is $11 \mathrm{~km}$ long and flows through southern urban neighborhoods of Recife. Tejipió Creek is $20 \mathrm{~km}$ long and flows through western neighborhoods of Recife. Both creeks receive high loads of untreated wastewater along their watercourse. The Capibaribe River's main stem meets the Pina Sound close to downtown Recife, then flows northward near the Port of Recife and finally out into the Atlantic Ocean. 
Pina Sound

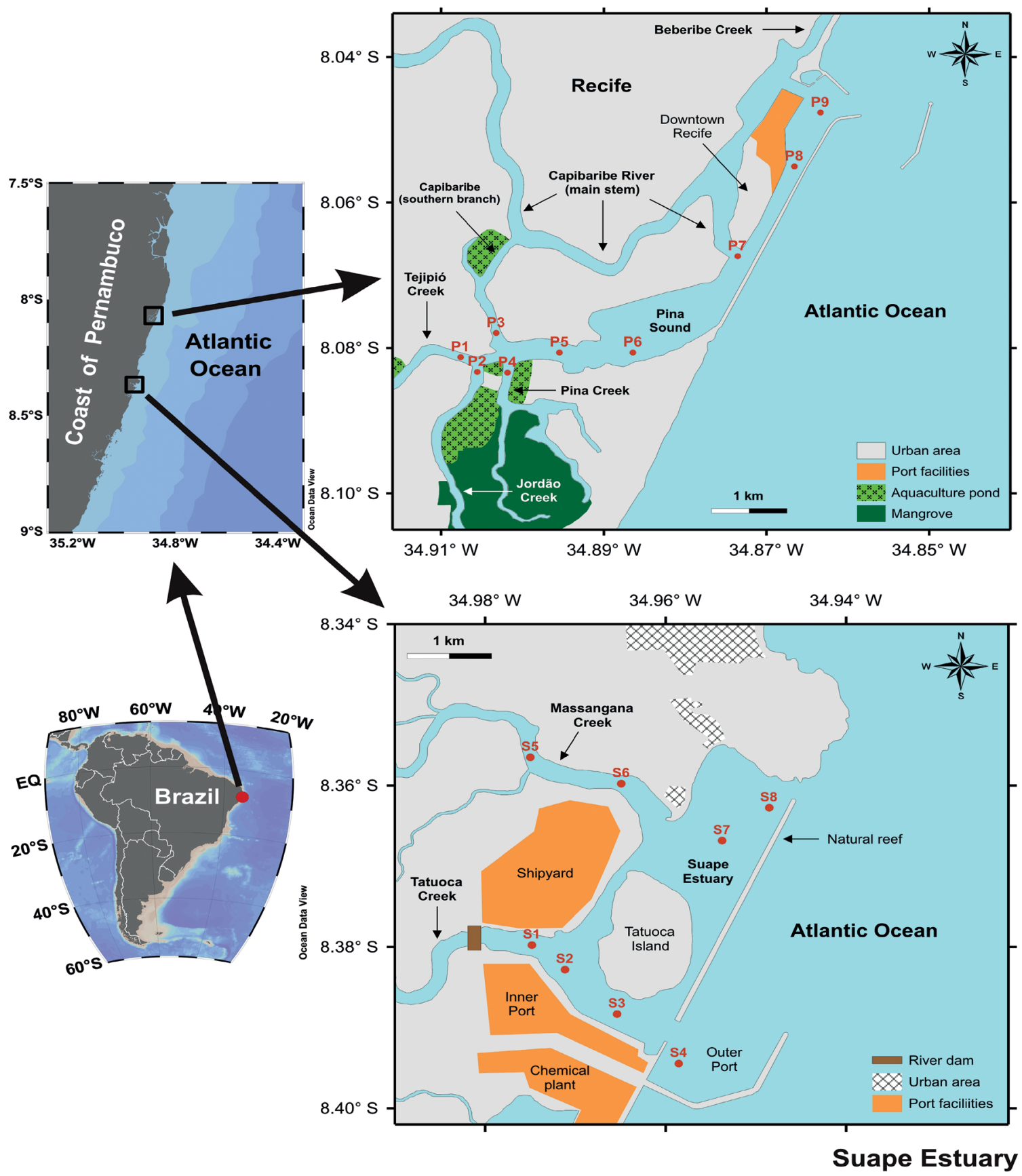

Figure 1. Geographical setting and sampling sites at Pina Sound (P1-P9) and Suape Estuary (S1-S8), coast of Pernambuco, northeastern Brazil.

Suape Estuary is located around $40 \mathrm{~km}$ south of Recife. It hosts the Port of Suape, and several chemical and manufacturing plants as well as shipyards. A natural reef separates brackish, estuarine waters from the ocean (Figure 1). Massangana and Tatuoca are small coastal creeks that flow into the estuary in its northern and southern portions, respectively. Massangana Creek is about $30 \mathrm{~km}$ long and flows mainly through sugarcane plantations. Tatuoca Creek is shorter (less than $8 \mathrm{~km}$ long) and is surrounded by chemical plants, including an oil refinery. The Port of Suape is divided into inner and outer sections, the former being located on the lower Tatuoca Creek. In order to facilitate dredging operations in the inner port, a dam has been constructed across Tatuoca Creek to control downstream water and sediment flows (Figure 1). 


\section{SAMPLING}

Surface sediment samples (top $10 \mathrm{~cm}$ ) were collected using a stainless steel van Veen grab sampler. Field trips were carried out on Suape Estuary and Pina Sound in July and December 2011, respectively. Samples were collected at nine sites (P1-P9) on Pina Sound, including the watersheds of the major local streams (Figure 1). In the Suape Estuary, samples were collected at eight sites on the Tatuoca (S1-S4) and Massangana (S5-S8) creeks (Figure 1). All sediments were stored in previously combusted $\left(450{ }^{\circ} \mathrm{C}\right.$ for $\left.4 \mathrm{~h}\right)$ aluminum containers, maintained temporarily in a cooler, and frozen at $-22{ }^{\circ} \mathrm{C}$ upon arrival in the laboratory. Afterwards, they were freeze-dried, homogenized and stored at room temperature until further analysis.

\section{GRAIN SIZE ANALYSIS}

Grain size was gravimetrically determined in accordance with Suguio (1973). Briefly, sedimentary organic matter was removed with hydrogen peroxide prior to particle size fractionation. Then, the sediments were sieved through a $63 \mu \mathrm{m}$ sieve for separating coarse (sand) and fine (silt + clay) fractions. The latter were further separated (into silt and clay) in a homogenized suspension according to particle sedimentation velocities. Calculations were made using the SysGran 3.0 software (Camargo, 2006).

\section{Chemical analysis}

Sample extraction and clean-up was based on the method reported in UNEP (1992) and described elsewhere (e.g., Combi et al., 2013). Briefly, an amount of $20 \mathrm{~g}$ of dry sediment was Soxhlet-extracted with $80 \mathrm{~mL}$ of a $50 \%$ mixture of residue grade $n$-hexane and dichloromethane for 8 hours. Before extraction, surrogates (PCB-103 and PCB-198) were added to all samples, blanks and reference material from the National Institute of Standards and Technology (NIST - SRM 1944). The extract was purified in a chromatographic column filled with $5 \%$ deactivated alumina. For determination of OCPs, the extract was injected in splitless mode in an Agilent Technologies gas chromatograph equipped with an electron capture detector (GC-ECD). A $30 \mathrm{~m}$ x $0.25 \mathrm{~mm}$ i.d. fusedsilica column with $0.25 \mu \mathrm{m}$ bonded phase (HP-5ms, Agilent $\mathrm{J} \& \mathrm{~W}$ ) was installed in the $\mathrm{GC}$. The oven temperature was programmed to $70{ }^{\circ} \mathrm{C}$ for $1 \mathrm{~min}$, increasing at $40^{\circ} \mathrm{C} \mathrm{min}{ }^{-1}$ to 170 ${ }^{\circ} \mathrm{C}$, increasing at $3{ }^{\circ} \mathrm{C} \mathrm{min}^{-1}$ to $195{ }^{\circ} \mathrm{C}$ (holding this temperature for $3 \mathrm{~min}$ ), increasing at $0.5^{\circ} \mathrm{C} \mathrm{min}^{-1}$ to $210^{\circ} \mathrm{C}$ (holding for $5 \mathrm{~min}$ ), and increasing at $20^{\circ} \mathrm{C} \mathrm{min}^{-1}$ to $300^{\circ} \mathrm{C}$ with a final hold time of $10 \mathrm{~min}$. PCBs were quantitatively analyzed by an Agilent 6890 gas chromatograph coupled to a 5973N mass spectrometer (GC-MS) in the selected ion monitoring (SIM) mode. Oven temperature was programmed as follows: $75^{\circ} \mathrm{C}$ for $3 \mathrm{~min}$, raised at $15^{\circ} \mathrm{C} \mathrm{min}^{-1}$ to $150^{\circ} \mathrm{C}$, then raised at $2.0^{\circ} \mathrm{C}$ $\mathrm{min}^{-1}$ to $260{ }^{\circ} \mathrm{C}$ and finally at $20^{\circ} \mathrm{C} \mathrm{min}^{-1}$ to $300^{\circ} \mathrm{C}$ with a final hold for 10 minutes. The interface, ion source and quadrupole temperatures were $280{ }^{\circ} \mathrm{C}, 300^{\circ} \mathrm{C}$ and $200{ }^{\circ} \mathrm{C}$, respectively.

\section{QUALITY ASSURANCE AND QUALITY CONTROL}

Certified standards at nine different concentrations were used for preparation of the analytical curve. Target analyte identification was based on GC retention times of certified standards. PCB identification was also based on their mass-to-charge $(\mathrm{m} / \mathrm{z})$ ratios. The analytical method was in agreement with quality control criteria described by Wade and Cantillo (1994), and included analysis of procedural blanks, matrix spikes, precision tests and standard reference material (SRM). The method detection limits (MDL) were calculated as three times the standard deviation of seven replicates of spiked sediment samples. The average MDL for all analytes was $0.30 \mathrm{ng} \mathrm{g}^{-1}$ dry weight, ranging from 0.02 to $1.94 \mathrm{ng} \mathrm{g}^{-1}$. They are provided in Tables 1 and 2 as values preceded by the less-than sign. Method quantitation limits (MQL) were not calculated. All concentrations are expressed on a dry weight (dw) basis. Unless otherwise noted, values below MDL were set at zero for calculation purposes. Concentrations reported for analytes are corrected for surrogate recovery as described by Wade and Cantillo (1994).

\section{STATISTICAL ANALYSIS}

Statistical analyses were carried out using the PAST 3.13 software (Hammer et al., 2001). A couple of one-way analyses of variance (ANOVA) were performed for comparing contamination ( $\Sigma$ PCBs, $\Sigma$ DDTs) between upper and lower Pina Sound. In order to meet the assumptions of the ANOVA, the data set was transformed using an inverse square root function: $(x+1)^{-0.5}$. According to the ShapiroWilk test, the transformed data set was normally distributed at all treatment levels $(\mathrm{W}>0.88, p>0.30)$. Homogeneity of variances was assessed using the Levene's test. Data variance between upper and lower sites was homogeneous for $\Sigma$ DDTs $(p=0.37)$ and approximately homogeneous for $\Sigma$ PCBs $(p=0.042)$.

At Suape Estuary, a Kruskal-Wallis test was performed for comparing PCB contamination between sampling sites in the watersheds of the Tatuoca and Massangana creeks. In this case, a non-parametric test 
Table 1. Concentration of organochlorines ( $\mathrm{ng} \mathrm{g}^{-1}$ dry weight) in sediment samples from Pina Sound, coast of Pernambuco, northeastern Brazil.

\begin{tabular}{|c|c|c|c|c|c|c|c|c|c|}
\hline \multirow[b]{2}{*}{ ID } & \multicolumn{9}{|c|}{ Concentration (ng g ${ }^{-1}$ dry weight) } \\
\hline & OM00232 & OM00228 & OM00236 & OM00224 & OM00220 & OM00216 & OM00212 & OM00208 & OM00204 \\
\hline Site & $\mathrm{P} 1$ & P2 & P3 & P4 & P5 & P6 & P7 & $\mathrm{P} 8$ & P9 \\
\hline$\Sigma$ PCBs & $<0.51$ & 2.14 & $<0.51$ & 15.0 & 3.8 & 9.39 & 4.92 & 2.08 & 1.95 \\
\hline$\Sigma$ DDTs & 21.4 & 2.96 & $<0.27$ & 6.01 & 3.00 & 5.77 & 3.86 & 2.99 & 1.13 \\
\hline$\Sigma \mathrm{HCHs}$ & $<0.58$ & $<0.58$ & $<0.58$ & $<0.58$ & $<0.58$ & $<0.58$ & $<0.58$ & $<0.58$ & $<0.58$ \\
\hline$\Sigma \mathrm{CHLs}$ & $<1.94$ & $<1.94$ & $<1.94$ & $<1.94$ & $<1.94$ & $<1.94$ & $<1.94$ & $<1.94$ & $<1.94$ \\
\hline HCB & $<0.16$ & $<0.16$ & $<0.16$ & $<0.16$ & $<0.16$ & $<0.16$ & $<0.16$ & $<0.16$ & $<0.16$ \\
\hline Mirex & $<0.48$ & $<0.48$ & $<0.48$ & $<0.48$ & $<0.48$ & $<0.48$ & $<0.48$ & $<0.48$ & $<0.48$ \\
\hline Methoxychlor & $<0.48$ & $<0.48$ & $<0.48$ & $<0.48$ & $<0.48$ & $<0.48$ & $<0.48$ & $<0.48$ & $<0.48$ \\
\hline$\alpha$-Endosulfan & $<0.32$ & $<0.32$ & $<0.32$ & $<0.32$ & $<0.32$ & $<0.32$ & $<0.32$ & $<0.32$ & $<0.32$ \\
\hline$\beta$-Endosulfan & $<0.32$ & $<0.32$ & $<0.32$ & $<0.32$ & $<0.32$ & $<0.32$ & $<0.32$ & $<0.32$ & $<0.32$ \\
\hline Aldrin & $<0.26$ & $<0.26$ & $<0.26$ & $<0.26$ & $<0.26$ & $<0.26$ & $<0.26$ & $<0.26$ & $<0.26$ \\
\hline Dieldrin & $<0.32$ & $<0.32$ & $<0.32$ & $<0.32$ & $<0.32$ & $<0.32$ & $<0.32$ & $<0.32$ & $<0.32$ \\
\hline Isodrin & $<0.51$ & $<0.51$ & $<0.51$ & $<0.51$ & $<0.51$ & $<0.51$ & $<0.51$ & $<0.51$ & $<0.51$ \\
\hline
\end{tabular}

Legend: $\Sigma$ PCBs $=$ sum of 51 congeners (refer to text for full list); $\Sigma$ DDTs $=$ sum of $p, p^{\prime}$-DDT, $o, p^{\prime}$-DDT, $p, p^{\prime}$-DDD, $o, p^{\prime}$-DDD, $p, p^{\prime}$-DDE and $o, p^{\prime}-$ $\mathrm{DDE} ; \Sigma \mathrm{HCHs}=$ sum of $\alpha-\mathrm{HCH}, \beta-\mathrm{HCH}, \gamma-\mathrm{HCH}$ and $\delta$-HCH; $\Sigma$ CHLs $=$ sum of $\alpha$-chlordane, $\gamma$-chlordane, oxychlordane, heptachlor, heptachlor trans-epoxide and heptachlor cis-epoxide.

Table 2. Concentration of organochlorines (ng g ${ }^{-1}$ dry weight) in sediment samples from Suape Estuary, coast of Pernambuco, northeastern Brazil.

\begin{tabular}{|c|c|c|c|c|c|c|c|c|}
\hline \multirow[b]{2}{*}{ ID } & \multicolumn{8}{|c|}{ Concentration (ng g ${ }^{-1}$ dry weight) } \\
\hline & OM00028 & OM00048 & OM00024 & OM00019 & OM00044 & OM00046 & OM00040 & OM00036 \\
\hline Site & S1 & $\mathrm{S} 2$ & S3 & S4 & S5 & S6 & S7 & S8 \\
\hline$\Sigma$ PCBs & 2.95 & 1.34 & 0.18 & 2.24 & 0.78 & $<0.02$ & $<0.02$ & $<0.02$ \\
\hline$\Sigma$ DDTs & $<0.27$ & $<0.27$ & 2.20 & 1.14 & $<0.27$ & $<0.27$ & $<0.27$ & $<0.27$ \\
\hline$\Sigma \mathrm{HCHs}$ & $<0.58$ & $<0.58$ & $<0.58$ & $<0.58$ & $<0.58$ & $<0.58$ & $<0.58$ & $<0.58$ \\
\hline$\Sigma \mathrm{CHLs}$ & $<1.94$ & $<1.94$ & $<1.94$ & $<1.94$ & $<1.94$ & $<1.94$ & $<1.94$ & $<1.94$ \\
\hline $\mathrm{HCB}$ & $<0.16$ & $<0.16$ & $<0.16$ & $<0.16$ & $<0.16$ & $<0.16$ & $<0.16$ & $<0.16$ \\
\hline Mirex & $<0.48$ & $<0.48$ & $<0.48$ & $<0.48$ & $<0.48$ & $<0.48$ & $<0.48$ & $<0.48$ \\
\hline Methoxychlor & $<0.48$ & $<0.48$ & $<0.48$ & $<0.48$ & $<0.48$ & $<0.48$ & $<0.48$ & $<0.48$ \\
\hline$\alpha$-Endosulfan & $<0.32$ & $<0.32$ & $<0.32$ & $<0.32$ & $<0.32$ & $<0.32$ & $<0.32$ & $<0.32$ \\
\hline$\beta$-Endosulfan & $<0.32$ & $<0.32$ & $<0.32$ & $<0.32$ & $<0.32$ & $<0.32$ & $<0.32$ & $<0.32$ \\
\hline Aldrin & $<0.26$ & $<0.26$ & $<0.26$ & $<0.26$ & $<0.26$ & $<0.26$ & $<0.26$ & $<0.26$ \\
\hline Dieldrin & $<0.32$ & $<0.32$ & $<0.32$ & $<0.32$ & $<0.32$ & $<0.32$ & $<0.32$ & $<0.32$ \\
\hline Isodrin & $<0.51$ & $<0.51$ & $<0.51$ & $<0.51$ & $<0.51$ & $<0.51$ & $<0.51$ & $<0.51$ \\
\hline
\end{tabular}

Legend: $\Sigma$ PCBs $=$ sum of 51 congeners (refer to text for full list); $\Sigma$ DDTs = sum of $p, p^{\prime}$-DDT, $o, p^{\prime}$-DDT, $p, p^{\prime}$-DDD, $o, p^{\prime}$-DDD, $p, p^{\prime}$-DDE and o, $\mathrm{p}^{\prime}-$ DDE; $\Sigma \mathrm{HCHs}=$ sum of $\alpha-\mathrm{HCH}, \beta-\mathrm{HCH}, \gamma-\mathrm{HCH}$ and $\delta$-HCH; $\Sigma$ CHLs $=$ sum of $\alpha$-chlordane, $\gamma$-chlordane, oxychlordane, heptachlor, heptachlor trans-epoxide and heptachlor cis-epoxide.

was chosen because the data set did not fit the ANOVA assumptions even after transformation. Spearman's rank order correlation analysis was performed for assessing a potential association between contaminants and grain size fractions in the sediments of both estuaries. In this case, a non-parametric alternative was used due to lack of normality consistency across the full data set after transformation.
A one-way multivariate analysis of variance (MANOVA) was performed for comparing overall contamination between Pina Sound and Suape Estuary. Response variables were concentrations of $\Sigma$ PCBs and $\Sigma$ DDTs in sediment. The data set was transformed using the same function described above. Mardia's tests were employed for checking multivariate normality of the transformed data. Multivariate skewness corrected for small samples 
$\left(\mathrm{b}_{1,2}=5.21, p=0.27\right)$ and multivariate kurtosis $\left(\mathrm{b}_{2,2}=-0.57\right.$, $p=0.57$ ) exhibited normal distributions. Homoscedasticity was checked using Box's M test of equality of covariance matrices. This test revealed that covariance matrices are equivalent across the estuaries $(\mathrm{M}=0.90, \mathrm{~F}=0.26, p=0.86)$.

\section{RESULTS}

Most sediments from Pina Sound (P1, P3, P4, P6 and P8) consisted of uniform mixtures of sand, silt and clay ( $>20 \%$ of each fraction) (Figure 2). According to the classification proposed by Shepard (1954), sites P5 and P7 were characterized as silty sand (52\% sand, 38\% silt) and clayey silt (59\% silt, 37\% clay), respectively. Sites P2 and P9 were basically comprised of sand (79\%) and silt (80\%), respectively (Figure 2). Grain size distribution was more heterogeneous at Suape Estuary. Muddy sediments were prevalent in the watersheds of Tatuoca Creek where sites S1, S2 and S4 were classified as silty clay (59\% clay, $39 \%$ silt), silty clay (61\% clay, 34\% silt) and clayey silt (55\% silt, $42 \%$ clay), respectively. In contrast, coarse sediments dominated the watersheds of Massangana Creek. According to Shepard (1954), site S5 was classified as clayey sand (54\% sand, 32\% clay) while sites S6 and S8 were basically comprised of sand $(>98 \%)$. At Suape Estuary, uniform mixtures of each fraction were found at sites S3 and S7 (Figure 2).

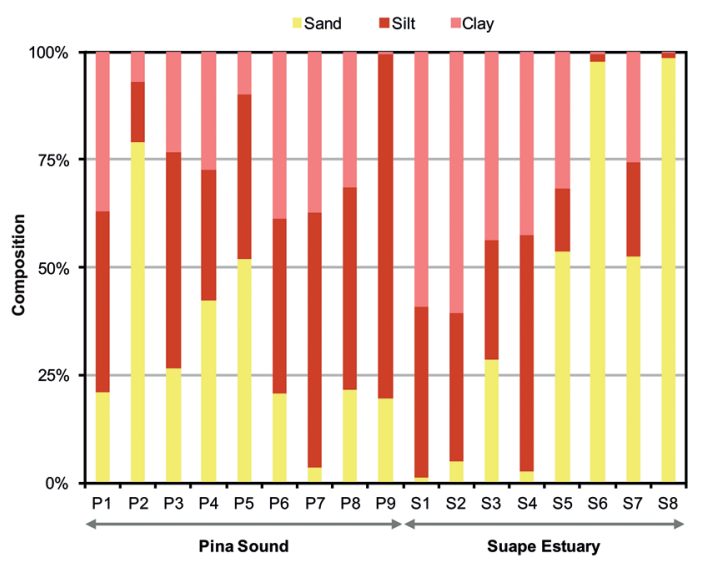

Figure 2. Distribution of grain size in sediments collected at Pina Sound (P1-P9) and Suape Estuary (S1-S8), coast of Pernambuco, northeastern Brazil.

A suite of 51 PCB congeners from di- through decachlorinated biphenyls (CBs) was investigated in the sediments of Pina Sound and Suape Estuary. Target PCB congeners and isomers were IUPAC Nos. 8, 18, 28, 31, 33, 44,
49, 52, 56/60 (co-eluted), 66, 70, 74, 77, 81, 87, 95, 97, 99, $101,105,110,114,118,123,126,128,132,138,141,149$, $151,153,156,157,158,167,169,170,174,177,180$, 183, 187, 189, 194, 195, 201, 203, 206, and 209. Total PCB concentrations ranged from $<0.51$ to $15.0 \mathrm{ng} \mathrm{g}^{-1}$ in sediments collected at Pina Sound (Table 1). Only 16 congeners (IUPAC Nos. 49, 52, 74, 95, 99, 101, 110, 118, 138, $141,149,151,153,158,183$, and 187) from tetra- through hepta-CBs were detected above MDL in these samples. At Suape Estuary, total PCBs ranged from $<0.02$ to $2.95 \mathrm{ng}$ $\mathrm{g}^{-1}$ (Table 2), whereas only 9 congeners (IUPAC Nos. 28, $70,74,95,101,110,138,149$, and 153) from tri- through hexa-CBs were found in sediment samples.

A total of 24 OCPs were investigated in estuarine sediments, including $\mathrm{HCB}$, aldrin, dieldrin, isodrin, $\alpha$-endosulfan, $\beta$-endosulfan, mirex, methoxychlor, $\Sigma$ $\mathrm{HCHs}$ (sum of $\alpha-\mathrm{HCH}, \beta-\mathrm{HCH}, \gamma-\mathrm{HCH}$ and $\delta-\mathrm{HCH}$ ), $\Sigma$ CHLs (sum of $\alpha$-chlordane, $\gamma$-chlordane, oxychlordane, heptachlor, heptachlor trans-epoxide and heptachlor cis-epoxide), and $\Sigma$ DDTs (sum of $p, p^{\prime}$-DDT, $o, p^{\prime}$-DDT, $p, p^{\prime}$-DDD, $o, p^{\prime}$-DDD, $p, p^{\prime}$-DDE and $o, p^{\prime}$-DDE). They were not detected above MDL in any samples from either estuary, with exception of DDTs (see Tables 1 and 2). Concentrations of total DDTs ranged from $<0.27$ to $21.4 \mathrm{ng} \mathrm{g}^{-1}$ in samples collected at Pina Sound. At Suape Estuary, total DDTs in sediments ranged from $<0.27$ to $2.20 \mathrm{ng} \mathrm{g}^{-1}$.

\section{DISCUSSION}

\section{POLYCHLORINATED BIPHENYLS}

Mean concentration of total PCBs in sediments from Pina Sound was $4.37 \pm 4.92 \mathrm{ng} \mathrm{g}^{-1}$ (standard deviation, SD). This is about one order of magnitude lower than the average contamination found at Guanabara Bay and Santos Estuary - the most industrialized areas along the Brazilian coast (Table 3) (Bícego et al., 2006; Souza et al., 2008). The highest level at Pina Sound was detected at P4 (15.0 ng $\left.\mathrm{g}^{-1}\right)$, a site surrounded by a small slum and shrimp aquaculture ponds located at Pina Creek (see Figure 1). Despite a mangrove forest upstream, Pina Creek receives untreated sewage from slums located on its banks. Sites P6 (9.39 $\mathrm{ng} \mathrm{g}^{-1}$ ) and P7 (4.92 $\mathrm{ng} \mathrm{g}^{-1}$ ) also exhibited high local levels of total PCBs (Table 1). The former is located next to a large slum (Brasília Teimosa) while the latter is located in the watercourse of the Capibaribe River's main stem - the largest local stream - that receives runoff from northern and western neighborhoods of Recife (see Figure 
Table 3. Average concentration of persistent organic pollutants (ng $\mathrm{g}^{-1}$ dry weight) in sediments from Brazilian coastal environments.

\begin{tabular}{|c|c|c|c|c|c|c|c|c|c|c|c|c|}
\hline Location, State & Survey & $\mathrm{n}$ & $\begin{array}{c}\Sigma \\
\text { PCBs }\end{array}$ & HCB & $\begin{array}{c}\Sigma \\
\text { DDTs }\end{array}$ & $\begin{array}{c}\Sigma \\
\mathrm{HCHs} \\
\quad \text { (ng }\end{array}$ & $\begin{array}{c}\Sigma \\
\text { CHLs } \\
\sigma^{-1} \text { dry u }\end{array}$ & $\begin{array}{c}\Sigma \\
\text { DRNs } \\
\text { ight) }\end{array}$ & $\begin{array}{c}\Sigma \\
\text { SFNs }\end{array}$ & Mirex & DMDT & Reference \\
\hline $\begin{array}{l}\text { Jaguaribe Estuary, } \\
\mathrm{CE}\end{array}$ & 2011 & 5 & & 1.95 & 7.53 & 1.58 & 28.9 & nd & 67.8 & & 2.29 & $\begin{array}{l}\text { Oliveira et } \\
\text { al. }(2016)^{\mathrm{a}}\end{array}$ \\
\hline Pina Sound, PE & 2011 & 9 & 4.37 & $<0.16$ & 5.24 & $<0.58$ & $<1.94$ & $<0.51$ & $<0.32$ & $<0.48$ & $<0.48$ & This study \\
\hline Suape Estuary, PE & 2011 & 8 & 0.94 & $<0.16$ & 0.42 & $<0.58$ & $<1.94$ & $<0.51$ & $<0.32$ & $<0.48$ & $<0.48$ & This study \\
\hline Guanabara Bay, RJ & 2003-04 & 5 & 80.6 & 0.24 & 16.1 & 1.06 & 3.61 & 4.52 & 1.27 & & & $\begin{array}{l}\text { Souza et } \\
\text { al. }(2008)^{\mathrm{c}}\end{array}$ \\
\hline Santos Estuary, SP & 2000 & 9 & 36.0 & 3.15 & 3.27 & 0.10 & $<0.10$ & $<0.10$ & & $<0.10$ & & $\begin{array}{l}\text { Bícego et } \\
\text { al. }(2006)^{d}\end{array}$ \\
\hline Guaratuba Bay, PR & 2010 & 22 & 0.87 & $<\mathrm{LQ}$ & 0.08 & $<\mathrm{LQ}$ & 0.06 & $<\mathrm{LQ}$ & $<\mathrm{LQ}$ & $<\mathrm{LQ}$ & $<\mathrm{Q}$ & $\begin{array}{l}\text { Combi et } \\
\text { al. }(2013)^{\mathrm{e}}\end{array}$ \\
\hline $\begin{array}{l}\text { Florianópolis Bay, } \\
\text { SC }\end{array}$ & 2009 & 5 & $<0.51$ & $<0.14$ & 4.27 & 0.17 & $<0.03$ & $<0.13$ & $<0.34$ & $<0.16$ & & $\begin{array}{l}\text { Souza et } \\
\text { al. }(2012)^{\mathrm{f}}\end{array}$ \\
\hline
\end{tabular}

${ }^{\mathrm{a}} \sum \mathrm{DDT}=\operatorname{sum}$ of $p, p^{\prime}$-DDT, $o, p^{\prime}-\mathrm{DDT}, p, p^{\prime}$-DDD, and $p, p^{\prime}$-DDE; $\sum \mathrm{HCH}=\operatorname{sum}$ of $\alpha-\mathrm{HCH}, \beta-\mathrm{HCH}$ and $\gamma-\mathrm{HCH} ; \sum \mathrm{CHL}=$ heptachlor; $\sum \mathrm{SFN}=$ sum of $\alpha$-endosulfan and $\beta$-endosulfan; riverine sediments were excluded. ${ }^{\mathrm{b}} \sum \mathrm{PCB}=$ sum of 51 congeners; $\sum$ DDT $=$ sum of $p, p^{\prime}$-DDT, $o, p^{\prime}$-DDT, $p, p^{\prime}$-DDD, $o, p^{\prime}$-DDD $, p, p^{\prime}$-DDE and $o, p^{\prime}$-DDE. ${ }^{c} \sum \mathrm{PCB}=$ sum of 7 congeners; $\sum \mathrm{DDT}=\operatorname{sum}$ of $p, p^{\prime}$-DDT, $o, p^{\prime}$-DDT, $p, p^{\prime}$-DDD, $p, p^{\prime}$-DDE and $o, p^{\prime}-$ $\mathrm{DDE} ; \sum \mathrm{HCH}=\gamma-\mathrm{HCH} ; \sum \mathrm{CHL}=$ sum of heptachlor and heptachlor epoxide; $\sum \mathrm{DRN}=$ sum of aldrin, dieldrin and endrin; $\sum \mathrm{SFN}=\alpha$-endosulfan. ${ }^{\mathrm{d}} \sum \mathrm{PCB}=$ sum of 30 congeners; $\sum \mathrm{DDT}=$ sum of $p, p^{\prime}$-DDT, $o, p^{\prime}$-DDT, $p, p^{\prime}$-DDD, $o, p^{\prime}$-DDD, $p, p^{\prime}-\mathrm{DDE}$ and $o, p^{\prime}-\mathrm{DDE} ; \sum \mathrm{HCH}=\gamma-\mathrm{HCH}$ and $\delta$-HCH. ${ }^{e} \sum \mathrm{PCB}=$ sum of 51 congeners; $\sum \mathrm{DDT}=$ sum of $p, p^{\prime}$-DDT, $o, p^{\prime}-\mathrm{DDT}, p, p^{\prime}$-DDD, $o, p^{\prime}-\mathrm{DDD}, p, p^{\prime}-\mathrm{DDE}$ and $o, p^{\prime}-\mathrm{DDE} ; \sum \mathrm{CHL}=$ sum of $\alpha$-chlordane, $\gamma$-chlordane, oxychlordane, heptachlor, heptachlor trans-epoxide and heptachlor cis-epoxide; individual limits of quantitation (LQ) are not specified in the paper. ${ }^{\mathrm{f}} \sum$ DDT and $\sum \mathrm{HCH}$ are not specified in the paper.

1). Despite sediments of the most contaminated sites being muddy (over $57 \%$ of silt + clay), no significant correlation was observed between mud and $\Sigma$ PCBs in the sediments of Pina Sound (Spearman correlation, $\mathrm{r}_{\mathrm{s}}=-0.05$, $\mathrm{n}=9, p=0.90)$.

Upper Pina Sound is formed by the confluence of several narrow streams. It has restricted marine influence and water circulation (Nascimento et al., 2003). In contrast, lower Pina Sound is wider and has marked marine influence (Nascimento et al., 2003). The sampling sites located on the upper Pina Sound (P1-P5) are noticeably more degraded than those located on the lower Pina Sound (P6-P9). In spite of this, no significant difference was observed in levels of PCBs between sediments collected on the upper and lower Pina Sound (ANOVA, $F=1.07, \mathrm{df}=1$, $p=0.34$ ), indicating widespread PCB sources throughout the study area.

At Suape Estuary, the concentration of PCBs in sediments averaged $0.94 \mathrm{ng} \mathrm{g}^{-1}(\mathrm{SD}=1.1)$. This is similar to the average levels detected at Guaratuba Bay in southern Brazil (Table 3) (Combi et al., 2013). The highest local levels were found at sites S1 (2.95 $\left.\mathrm{ng} \mathrm{g}^{-1}\right)$ and S4 (2.24 ng $\mathrm{g}^{-1}$ ) that are close to a shipyard in the inner port and a ship berth in the outer port, respectively (Figure 1). According to the Kruskal-Wallis test, sediments collected from sampling sites in the watersheds of Tatuoca Creek (S1-S4) were significantly more contaminated than those under the influence of Massangana Creek (S5-S8) $(\mathrm{H}=4.3, \mathrm{df}=1, p=0.038)$. This is in agreement with grain size distribution in the northern and southern portions of the estuary. Muddy and sandy sediments were prevalent in the watersheds of Tatuoca and Massangana creeks, respectively (Figure 2). In addition, proximity to the Port of Suape may favor the occurrence of higher PCB levels in the lower Tatuoca Creek (see Figure 1). Overall, total PCBs were strongly associated with mud (silt + clay) in sediments of Suape Estuary (Spearman correlation, $\left.\mathrm{r}_{\mathrm{s}}=0.82, \mathrm{n}=7, p=0.038\right)$, particularly clay $\left(\mathrm{r}_{\mathrm{s}}=0.85\right.$, $\mathrm{n}=7, p=0.029$ ). These findings are in contrast with those observed at Pina Sound where a lack of significant correlation between contaminant and sediment grain size seems to be related to widespread PCB sources. This might suggest the existence of point sources and/or specific transport of PCBs to Suape Estuary. For example, PCBs might enter the estuary already bound to fine sedimentary particles.

The average distribution of PCB homolog groups in sediments of both estuaries was clearly distinct (Figure 3). Tetra- through hepta-CBs were found at Pina Sound with a prevalence of penta- and hexa-CBs that accounted for 35 and $49 \%$ of total $\mathrm{PCBs}$, respectively. In contrast, tri- through hexa-CBs were found at Suape Estuary where 
penta-CBs were the most prevalent group, accounting for $76 \%$ of total PCBs. These findings suggest that Pina Sound and Suape Estuary have distinct local sources of PCBs. Sediments from Suape Estuary seem to be contaminated by a lighter PCB mixture when compared to Pina Sound. Additionally, both estuarine PCB profiles also differ from the one observed in fish (Scomberomorus cavalla) caught off the coast of Pernambuco where tetra- through deca-CBs were detected in muscle and liver (Miranda and Yogui, 2016).

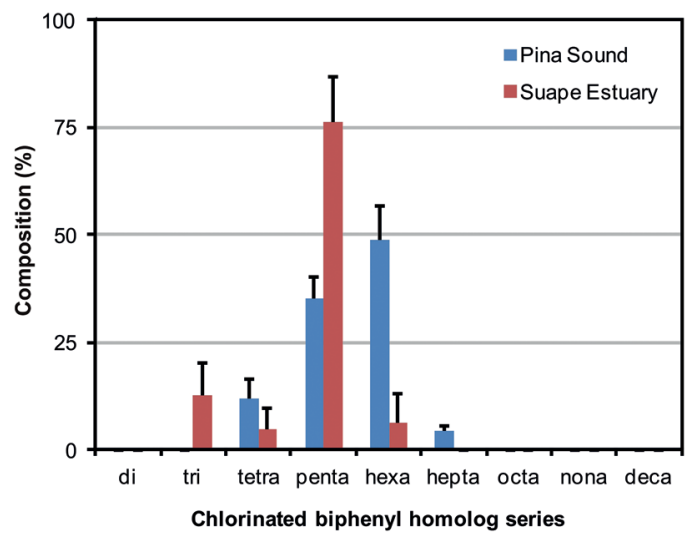

Figure 3. Average distribution of PCB homolog groups in sediments from Pina Sound and Suape Estuary, coast of Pernambuco, northeastern Brazil. Error bars denote standard error.

\section{DDT AND ITS METABOLITES}

Concentration of total DDTs in sediments from Pina Sound averaged $5.24 \mathrm{ng} \mathrm{g}^{-1}(\mathrm{SD}=6.37)$. This is on the same order of magnitude as mean contamination in several other coastal environments along the Brazilian coast (Table 3) (e.g., Bícego et al., 2006; Souza et al., 2012; Oliveira et al., 2016). The highest local contamination was found at site P1 (21.4 $\mathrm{ng} \mathrm{g}^{-1}$ ), located on Tejipió Creek (Figure 1). This stream receives runoff from residential areas of western Recife. High local levels of DDTs were also observed in sediments from sites P4 (6.01 $\mathrm{ng} \mathrm{g}^{-1}$ ) and P6 (5.77 ng $\left.\mathrm{g}^{-1}\right)$. These sites revealed the highest local PCB contamination as well. According to the ANOVA, there is no difference in concentrations of DDTs between sites located on the upper and lower Pina Sound $(\mathrm{F}=0.006, \mathrm{df}=1, p=0.94)$. Additionally, no significant correlation was observed between fine particles (i.e., silt + clay) and concentration of total DDTs in the sediments of Pina Sound (Spearman correlation, $\left.\mathrm{r}_{\mathrm{s}}=0.15, \mathrm{n}=9, p=0.68\right)$. Just like $\mathrm{PCBs}$, these findings support the hypothesis of widespread, diffuse local sources of POPs to the estuary.
Mean contamination of DDTs in sediments from Suape Estuary was $0.42 \mathrm{ng} \mathrm{g}^{-1}(\mathrm{SD}=0.82)$. This is at least one order of magnitude lower than the average DDT levels found in most Brazilian coastal environments (Table 3) (Souza et al., 2012; Oliveira et al., 2016; Souza et al., 2008; Bícego et al., 2006). Total DDTs at Suape Estuary were detected above MDL only at sites S3 (2.20 $\mathrm{ng} \mathrm{g}^{-1}$ ) and S4 (1.14 $\left.\mathrm{ng} \mathrm{g}^{-1}\right)$. Both of them consist of muddy sediment (over 71\%) and are located in the watercourse of Tatuoca Creek (Figures 1 and 2). All sampling sites in the Massangana Creek exhibited total DDTs below MDL (Table 2). According to the Spearman's rank order correlation analysis, no correlations were found between $\Sigma$ DDTs and sediment grain sizes (silt, clay) at Suape Estuary $\left(\mathrm{r}_{\mathrm{s}}<0.58, \mathrm{n}=7, p>0.23\right)$. This is in contrast to findings observed for PCBs in the same estuary, suggesting that DDTs have distinct local sources and transport pathways.

Dicofol has been suggested to be a recent source of DDTs to the environment (Qiu et al., 2005). It is a pesticide used for combating ticks and mites. High $o, p^{\prime}-\mathrm{DDT} / p, p^{\prime}-$ DDT ratios have been used as indicative of DDTs originated from dicofol (Qiu et al., 2005). Considering that $o, p^{\prime}$-DDT was not detected above MDL in any sediment samples from both Pina Sound and Suape Estuary, local use of dicofol can be ruled out as source of DDTs to the study areas. Miranda and Yogui (2016) draw similar conclusion in a study carried out on fish caught in coastal waters off Pernambuco.

In the environment, DDT tends to be metabolized into DDD and DDE under anaerobic and aerobic conditions, respectively (Aislabie et al., 1997). The ratio of its metabolites (DDD + DDE) to total DDTs ( $\Sigma$ DDTs) in sediment has been used for assessing historical input to the environment (Hong et al., 1999). If there are more metabolites than precursor compounds (i.e., ratio $>0.5$ ), local use of DDT has been assumed to be ancient (Hong et al., 1999; Minh et al., 2007). The ratio ranged from 0.74 to 1.0 in samples collected in Pina Sound and Suape Estuary, indicating that pesticide residues in sediment reflect past usage. This is in agreement with the DDT ban in Brazil that dates back to the 1980s for agriculture and the 1990s for public health (see Yogui et al., 2010). Similar trends have been observed in other Brazilian estuaries (e.g., Bícego et al., 2006; Combi et al., 2013; Oliveira et al., 2016). DDT-related compounds in the commercial formulation and sediment samples from Pernambuco estuaries are shown in Figure 4. A clear shift is observed between technical DDT and sediment residues. The metabolite $p, p$ '-DDE dominated composition in most samples collected at Pina Sound, suggesting degradation of $p, p$ '-DDT under aerobic conditions. Conversely, $o, p$ '-DDD 
was the only compound detected in sediments from Suape Estuary. This metabolite is derived from anaerobic degradation of $o, p$ '-DDT and was detected at sites S3 and S4. Considering that these sites (particularly S4) are located in areas of strong marine influence (i.e., oxic conditions), it is unlike that $o, p$ '-DDT conversion took place locally. The inner port navigation channel in the Suape Estuary is dredged periodically. Thus, $o, p$ '-DDD might have been transported to sites S3 and S4 from upstream, anoxic estuarine areas.

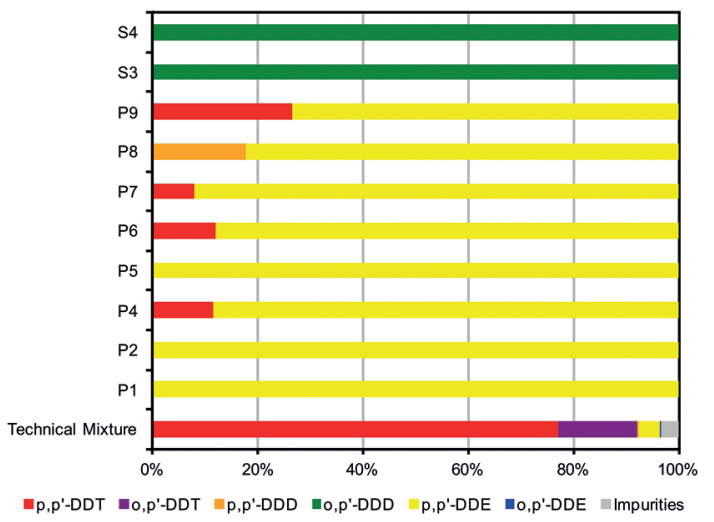

Figure 4. Composition of DDT-related compounds in sediments collected from Pina Sound (P1-P9) and Suape Estuary (S3-S4), coast of Pernambuco, northeastern Brazil. Composition of the DDT technical mixture (according to WHO, 1989) is also shown for purposes of comparison.

\section{OTHER CHLORINATED COMPOUNDS}

$\mathrm{HCB}$ has never been registered for use as a pesticide in Brazil although it has been unintentionally produced as a by-product in chemical plants (Nascimento et al., 2004; MMA, 2006). HCHs were used as both lindane $(\gamma-\mathrm{HCH})$ and the technical formulation (mixture of $\alpha, \beta, \gamma$ and $\delta$ isomers), being the second most used organochlorine pesticide in Brazil (MMA, 2006; Yogui et al., 2010). In addition, it is also known that lindane was legally applied as a wood preservative in Brazil until recently (Almeida et al., 2007). Despite their historical use, $\mathrm{HCB}$ and $\mathrm{HCH}$ isomers were below MDL in all sediment samples from both Pina Sound and Suape Estuary. This is likely associated with their high vapor pressure that facilitates volatilization to the atmosphere in tropical zones (Tanabe et al., 1993). In fact, HCB and $\mathrm{HCHs}$ seem not to be contaminants of major environmental concern in various matrices along the Brazilian coast (Yogui et al., 2003; Bícego et al., 2006; Fillmann et al., 2007; Oliveira et al., 2016).

Chlordane-related compounds ( $\alpha$-chlordane, $\gamma$-chlordane, oxychlordane, heptachlor, heptachlor trans-epoxide and heptachlor cis-epoxide) were below MDL in all samples from Pina Sound and Suape Estuary. In agreement with our findings, these chemicals have not been found in sediments from other Brazilian coastal environments such as Santos Estuary and Florianópolis Bay (Table 3) (Bícego et al., 2006; Souza et al., 2012). In fact, chlordane-related compounds were never extensively used in Brazil (MMA, 2006). Nonetheless, they were found at high levels in sediments of Jaguaribe Estuary (Table 3) (Oliveira et al., 2016). In Pernambuco, $\alpha$-chlordane and $\gamma$-chlordane have been found at detectable, quantifiable levels in tissues of offshore marine fish (Miranda and Yogui, 2016).

Aldrin, isodrin (an aldrin isomer), dieldrin, $\alpha$-endosulfan, $\beta$-endosulfan, mirex and methoxychlor were also below MDL in sediment samples collected from Pina Sound and Suape Estuary (Tables 1 and 2). In Brazil, aldrin and mirex were officially banned in 1998, whereas dieldrin has never been registered for official use in either agriculture or public health (MMA, 2006). In spite of this, there are records of the illegal use of aldrin, dieldrin and mirex in the backlands of Pernambuco in the late 1990s (Araújo et al., 2000). Endosulfan was phased out more recently in Brazil (i.e., 2013). Although not found at Pina Sound and Suape Estuary, endosulfan was used on crops along the coast of Pernambuco. High mean levels of $\alpha$-endosulfan were detected in sediments of Jaguaribe Estuary - an agricultural area heavily impacted by pesticides used on local crops (Table 3) (Oliveira et al., 2016; Gama et al., 2013).

\section{Pina Sound Vs. Suape Estuary}

Only PCBs and DDTs were found in the sediments of Pina Sound and Suape Estuary. Apparently, contamination levels are higher in the latter but data dispersion (i.e., standard deviation) is as great as the average. Thus, a MANOVA was performed for assessing statistical differences in contamination of both estuaries. According to the test, sediments from Pina Sound are significantly more contaminated than those from Suape Estuary (Pillai's trace $=0.53$, $\left.\mathrm{F}_{2,14}=7.8, p=0.005\right)$. These findings reflect differences in historical land use along the coast of Pernambuco as well as the phase-out of legacy POPs in Brazil. Land in the vicinity of Pina Sound has been occupied for centuries, it constitutes the core of the Recife metropolitan area and is densely populated. On the other hand, major anthropogenic impacts in the vicinity of Suape Estuary began about a decade ago as a consequence of a fast-paced industrialization process. Human activities at Suape became more intense after the prohibition of PCBs in manufacturing and the restriction of 
OCPs in agriculture - which date back to the 1980s. This is the most likely reason for the low levels of POPs found in such an industrialized estuary as Suape. This finding suggests that newly constructed industrial enterprises worldwide should follow similar trends, causing a lower impact in terms of POPs pollution.

According to the Spearman's rank order correlation analysis, no significant association was observed in the distribution of PCBs and DDTs in either Pina Sound $\left(\mathrm{r}_{\mathrm{s}}=0.45, \mathrm{n}=9, p=0.22\right)$ or Suape Estuary $\left(\mathrm{r}_{\mathrm{s}}=0.21, \mathrm{n}=8\right.$, $p=0.71)$. These findings indicate that there are distinct sources of PCBs and DDTs to the estuaries. In the case of PCBs, quite different congener profiles found in sediments provide additional evidence (Figure 3). For instance, PCB28 (trichlorinated biphenyl) comprised $22 \%$ of mean total PCBs in Suape Estuary while PCB-138 (hexachlorinated biphenyl) accounted for only $2.9 \%$ (Figure 5 ). In contrast, the latter congener comprised $15 \%$ of total PCBs at Pina Sound while the former was not detected in any of the sediment samples - as it was below the MDL (Figure 5).

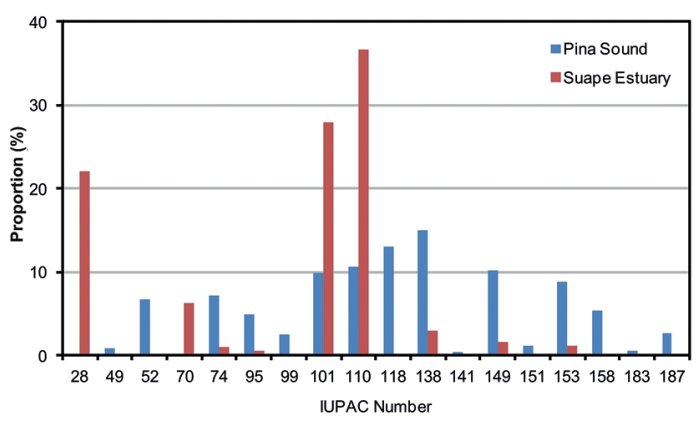

Figure 5. Average proportion of PCB congeners in sediments from Pina Sound and Suape Estuary, coast of Pernambuco, northeastern Brazil.

DDTs and PCBs can be used as chemical markers for agriculture/public health and industrial activities, respectively. Thus, the ratio of $\Sigma$ PCBs to $\Sigma$ PCBs $+\Sigma$ DDTs is a useful tool for providing information on predominant sources to the local environment. Values closer to zero indicate the prevalence of agriculture and/or public health usage, whereas values closer to one indicate a prevalence of industrial activities. The mean ratio calculated for Pina Sound was 0.49 , suggesting balanced inputs from both sources. This is in agreement with land use in Recife, an industrialized urban area with a historical application of pesticides for controlling the insect vectors of tropical diseases such as malaria and dengue fever. The calculated $\mathrm{PCB} /(\mathrm{PCB}+\mathrm{DDT})$ ratio at Suape Estuary was
0.75 , reflecting its main current land use. A prevalence of PCBs over DDTs in sediments has been also observed in industrialized areas such as Santos Estuary and Guanabara Bay, southeastern Brazil (Bícego et al., 2006; Souza et al., 2008).

\section{COMPARISON WITH COASTAL ENVIRONMENTS}

\section{AROUND THE WORLD}

Contamination of PCBs and DDTs in coastal sediments all over the world is reported in Table 4. Mean PCB levels at Suape Estuary $\left(<1 \mathrm{ng} \mathrm{g}^{-1}\right)$ are among the lowest of those shown in Table 4, being comparable to the sediment contamination in Yangtze Estuary, China. PCBs have not been widely used in China, and most PCB-containing electric equipment was sealed and dumped underground after the ban in the 1970s (Duan et al., 2013). In general, PCB levels at Pina Sound are similar to those found in developing countries of the Americas and Africa with mean contamination usually ranging from 1-10 $\mathrm{ng} \mathrm{g}^{-1}$ (Table 4) (Tolosa et al., 2010; El Nemr et al., 2013; Nouira et al., 2013). Nonetheless, the average concentration of PCBs in Pernambuco estuaries is about one order of magnitude lower than those found in coastal sediments of developed countries such as Australia, Belgium, the Netherlands and New Zealand (Van Ael et al., 2012; Birch and Taylor, 2000; Burggraaf et al., 1994). Additionally, industrialized coastal areas of developing countries that host major commercial ports are more contaminated by PCBs than are Pernambuco estuaries. This is the case of Bahia Blanca Estuary, Argentina and the Mediterranean coast of Egypt near Alexandria (Arias et al., 2013; Barakat et al., 2013).

The mean concentration of DDTs in sediments of Suape Estuary is similar to that of some other areas reported in Table 4, including Argentina, Belgium, the Netherlands, South Korea and Spain (Arias et al., 2011; Kim et al., 2008; Van Ael et al., 2012; Gómez et al., 2011). Average total DDTs at Pina Sound are on the same order of magnitude as those of several other areas, including Cuba, New Zealand and Portugal (Tolosa et al., 2010; Carvalho et al., 2009; Burggraaf et al., 1994). Unlike PCB contamination, there is no clear pattern for DDT levels among the study areas reported in Table 4. For instance, it is not possible to group them into developing and developed countries regarding concentration of DDTs in coastal sediments. These findings suggest that DDTs may be intrinsically related to complex local historical practices, including production sites, purpose of use (agriculture/ public health), total amount used and phase-out timeline. 
Table 4. Concentration of PCBs and DDTs (ng g-1 dry weight) in sediments of several coastal areas of the world.

\begin{tabular}{|c|c|c|c|c|c|c|c|c|}
\hline \multirow[t]{2}{*}{ Continent } & \multirow[t]{2}{*}{ Location } & \multirow[t]{2}{*}{ Survey } & \multirow[t]{2}{*}{$\mathrm{n}$} & \multicolumn{2}{|c|}{$\Sigma$ PCBs $\left(\right.$ ng g $\left.^{-1}\right)$} & \multicolumn{2}{|c|}{$\Sigma$ DDTs $\left(\right.$ ng g $\left.^{-1}\right)$} & \multirow{2}{*}{ Reference } \\
\hline & & & & Mean & Range & Mean & Range & \\
\hline \multirow[t]{5}{*}{ Americas } & $\begin{array}{c}\text { Pina Sound, } \\
\text { northeastern Brazil }\end{array}$ & 2011 & 9 & 4.37 & $<0.51-15.0$ & 5.24 & $<0.27-21.4$ & This study ${ }^{\mathrm{a}}$ \\
\hline & $\begin{array}{l}\text { Suape Estuary, } \\
\text { northeastern Brazil }\end{array}$ & 2011 & 8 & 0.94 & $<0.02-2.95$ & 0.42 & $<0.27-2.20$ & This study ${ }^{\mathrm{a}}$ \\
\hline & $\begin{array}{c}\text { Bahia Blanca Estuary, } \\
\text { Argentina }\end{array}$ & 2005-06 & 49 & & & 0.32 & $<\mathrm{LD}-1.93$ & $\begin{array}{l}\text { Arias et al. } \\
(2011)^{\mathrm{b}}\end{array}$ \\
\hline & $\begin{array}{c}\text { Bahia Blanca Estuary, } \\
\text { Argentina }\end{array}$ & $2005-06$ & 29 & 24.2 & $1.00-160$ & & & $\begin{array}{l}\text { Arias et al. } \\
(2013)^{\mathrm{c}}\end{array}$ \\
\hline & Cienfuegos Bay, Cuba & 2005 & 17 & 6.20 & $1.90-16.0$ & 2.00 & $<0.01-9.60$ & $\begin{array}{l}\text { Tolosa et al. } \\
\qquad(2010)^{\mathrm{d}}\end{array}$ \\
\hline \multirow[t]{3}{*}{ Africa } & $\begin{array}{l}\text { Mediterranean coast, } \\
\text { Egypt }\end{array}$ & 2005 & 12 & 50.9 & $2.29-377$ & 17.0 & $0.07-81.5$ & $\begin{array}{l}\text { Barakat et al. } \\
\qquad(2013)^{\mathrm{e}}\end{array}$ \\
\hline & Red Sea coast, Egypt & 2009 & 17 & 2.09 & $0.40-6.17$ & 0.080 & $0.003-0.46$ & $\begin{array}{l}\text { El Nemr et } \\
\text { al. }(2013)^{\mathrm{f}}\end{array}$ \\
\hline & Monastir Bay, Tunisia & $2007-08$ & 10 & 4.03 & $1.10-9.30$ & & & $\begin{array}{c}\text { Nouira et al. } \\
\qquad(2013)^{\mathrm{g}}\end{array}$ \\
\hline \multirow[t]{3}{*}{ Asia } & Yangtze Estuary, China & $2010-11$ & 25 & 0.13 & $0.02-0.34$ & & & $\begin{array}{l}\text { Duan et al. } \\
(2013)^{\mathrm{h}}\end{array}$ \\
\hline & Hugli Estuary, India & $1998-2000$ & 30 & & & 57.8 & $3.00-119$ & $\begin{array}{l}\text { Bhattacharya } \\
\text { et al. }(2003)^{\mathrm{i}}\end{array}$ \\
\hline & $\begin{array}{c}\text { Gwangyang Bay, South } \\
\text { Korea }\end{array}$ & 2006 & 3 & & & 0.13 & $0.061-0.20$ & $\begin{array}{l}\text { Kim et al. } \\
(2008)^{\mathrm{j}}\end{array}$ \\
\hline \multirow[t]{3}{*}{ Europe } & $\begin{array}{l}\text { Scheldt Estuary, } \\
\text { Belgium/Netherlands }\end{array}$ & 2010 & 36 & 31.5 & $1.91-368$ & 0.15 & $0.010-12.1$ & $\begin{array}{l}\text { Van Ael et al. } \\
\qquad(2012)^{\mathrm{k}}\end{array}$ \\
\hline & Coast of Portugal & 2007-08 & 11 & & & 5.57 & $0.72-14$ & $\begin{array}{l}\text { Carvalho et } \\
\text { al. }(2009)^{1}\end{array}$ \\
\hline & $\begin{array}{c}\text { Estuaries of Cantabria, } \\
\text { Spain }\end{array}$ & 2006 & 108 & & & 0.60 & $0.50-0.90$ & $\begin{array}{l}\text { Gómez et al. } \\
\qquad(2011)^{\mathrm{m}}\end{array}$ \\
\hline \multirow[t]{2}{*}{ Oceania } & Port Jackson, Australia & 1995 & 247 & 164 & $<0.50-1921$ & 77.0 & $<0.050-4875$ & $\begin{array}{l}\text { Birch and } \\
\text { Taylor } \\
(2000)^{\mathrm{n}}\end{array}$ \\
\hline & $\begin{array}{c}\text { Tauranga Harbour, New } \\
\text { Zeland }\end{array}$ & $1991-92$ & 15 & 13.7 & $<0.10-73.8$ & 2.62 & $<0.060-19.2$ & 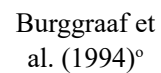 \\
\hline
\end{tabular}

$\bar{a} \sum \mathrm{PCB}=$ sum of 51 congeners; $\sum \mathrm{DDT}=$ sum of $p, p^{\prime}$-DDT, $o, p^{\prime}-\mathrm{DDT}, p, p^{\prime}$-DDD, $o, p^{\prime}$-DDD, $p, p^{\prime}$-DDE and $o, p^{\prime}-\mathrm{DDE} .{ }^{\mathrm{b}} \sum \mathrm{DDT}=\mathrm{sum}$ of $p, p^{\prime}-\mathrm{DDT}$, $p, p^{\prime}$-DDD and $p, p^{\prime}$-DDE; limit of detection (LD) is not specified in the paper. ${ }^{c} \sum \mathrm{PCB}=$ sum of 7 congeners. ${ }^{\mathrm{d}} \sum \mathrm{PCB}=$ sum of 11 congeners; $\sum$ $\mathrm{DDT}=$ sum of $p, p^{\prime}$-DDT, $p, p^{\prime}$-DDD and $p, p^{\prime}$-DDE. ${ }^{e} \sum \mathrm{PCB}=$ sum of 96 congeners; $\sum \mathrm{DDT}=$ sum of $p, p^{\prime}$-DDT, $o, p^{\prime}$-DDT, $p, p^{\prime}$-DDD, $o, p^{\prime}$-DDD, $p, p^{\prime}$-DDE and $o, p^{\prime}$-DDE; coastal lagoons were excluded. ${ }^{f} \sum \mathrm{PCB}=$ sum of 10 congeners; $\sum \mathrm{DDT}=$ sum of $p, p^{\prime}$-DDT, $p, p^{\prime}$-DDD and $p, p^{\prime}$-DDE. ${ }^{\mathrm{g}} \sum$ $\mathrm{PCB}=$ sum of 7 congeners. ${ }^{\mathrm{h}} \sum \mathrm{PCB}=$ sum of 23 congeners; surface sediments only. ${ }^{\mathrm{i}} \sum \mathrm{DDT}=$ sum of $p, p^{\prime}-\mathrm{DDT}, o, p^{\prime}-\mathrm{DDT}, p, p^{\prime}-\mathrm{DDE}$ and $o, p^{\prime}-$ DDE. ${ }^{j} \sum \mathrm{DDT}=$ sum of $p, p^{\prime}$-DDT, $o, p^{\prime}$-DDT, $p, p^{\prime}$-DDD, $o, p^{\prime}$-DDD, $p, p^{\prime}$-DDE and $o, p^{\prime}$-DDT. ${ }^{k} \sum$ PCB $=$ sum of 33 congeners; $\sum$ DDT $=$ sum of $p, p^{\prime}$-DDT, $o, p^{\prime}$-DDT, $p, p^{\prime}$-DDD, $o, p^{\prime}$-DDD, $p, p^{\prime}$-DDE and $o, p^{\prime}$-DDE. ${ }^{\prime} \sum$ DDT $=$ sum of $p, p^{\prime}$-DDT, $p, p^{\prime}$-DDE, $p, p^{\prime}$-DDD; only $5-15 \mathrm{~cm}$ of sediment was computed. ${ }^{\mathrm{m}} \sum \mathrm{DDT}=$ sum of $p, p^{\prime}-\mathrm{DDD}$ and $p, p^{\prime}-\mathrm{DDE} .{ }^{\mathrm{n}} \sum \mathrm{PCB}=$ mixture of Aroclors 1242 and $1254 ; \sum$ DDT $=$ sum of DDT, DDD and DDE. ${ }^{\circ} \sum \mathrm{PCB}=$ sum of Aroclor 1260 equivalent; $\sum \mathrm{DDT}=\operatorname{sum}$ of $p, p^{\prime}-\mathrm{DDT}, p, p^{\prime}-\mathrm{DDD}$ and $p, p^{\prime}-\mathrm{DDE}$.

It has been suggested that the high concentration of DDTs in sediments of Port Jackson, Australia was associated with chemical industries along estuarine shores (Birch and Taylor, 2000). In contrast, the high DDT levels in Hugli Estuary, India were dominated by $p, p$ '-DDT, evidencing recent input from public health and agricultural practices
(Bhattacharya et al., 2003). It is important to emphasize that DDT is still recommended by the World Health Organization for controlling malaria vectors (Anopheles spp.) in several countries despite the known human health consequences of its use (Eskenazi et al., 2009; WHO, 2011). 


\section{SEDIMENT QUALITY GUIDELINES}

Sediment quality guidelines (SQGs) have been proposed in order to assess potential adverse biological effects due to the presence of toxic chemicals in estuarine and marine sediments (e.g., Long et al., 1995; Macdonald et al., 1996). Long et al. (1995) developed values for effects range-low (ERL) and effects range-median (ERM), whereas MacDonald et al. (1996) derived values for threshold effects level (TEL) and probable effects level (PEL). ERL and TEL represent concentrations below which harmful biological effects are expected to be observed rarely. Conversely, ERM and PEL represent concentrations above which harmful biological effects are expected frequently. SQGs and chemical contamination in sediments from Pina Sound and Suape Estuary are provided in Figure 6. According to the approach of MacDonald et al. (1996), PCBs and DDTs were below TEL at all sampling sites in Suape Estuary (Figure 6a). On the other hand, $p, p$ '-DDE and $\Sigma$ DDTs were above the lower bound TEL respectively at seven (P1, P2, P4, P5, P6, P7 and P8) and at three (P1, $\mathrm{P} 4$ and $\mathrm{P} 6$ ) sites in Pina Sound, suggesting that occasional adverse effects may be expected (Figure 6a). An assessment of polycyclic aromatic hydrocarbons (PAHs) at Pina Sound detected dibenz $[a, h]$ anthracene above TEL values at several sites in the estuary (Maciel et al., 2015). Similar conclusions can be drawn for POPs at Pina Sound and Suape Estuary when considering the approach adopted by Long et al. (1995). Only one site (S3) exhibited $\Sigma$ DDTs above TEL at Suape Estuary while most sites (P1, P2, P4, P5, P6, P7 and P8) exceeded TEL for both $p, p$ '-DDE and $\Sigma$ DDTs (Figure 6b). No chemicals exceeded the upper bounds PEL and ERM (i.e., frequent adverse effects) in any of the sediment samples from either estuary.

\section{CONCLUSION}

Pina Sound is significantly more contaminated by legacy POPs than Suape Estuary, reflecting historical land use in the vicinity of these estuaries. The PCB profile in the surface sediments of Suape Estuary is lighter than that found in Pina Sound, suggesting distinct local sources. Levels of PCBs in the estuarine sediments of Pernambuco are below those found not only in coastal environments of developed countries but also in heavily industrialized areas of developing countries. In agreement with the DDT phase-out in Brazil, past pesticide usage in the study areas was identified due to the prevalence of DDT metabolites in all sediment samples. In general, the concentration of
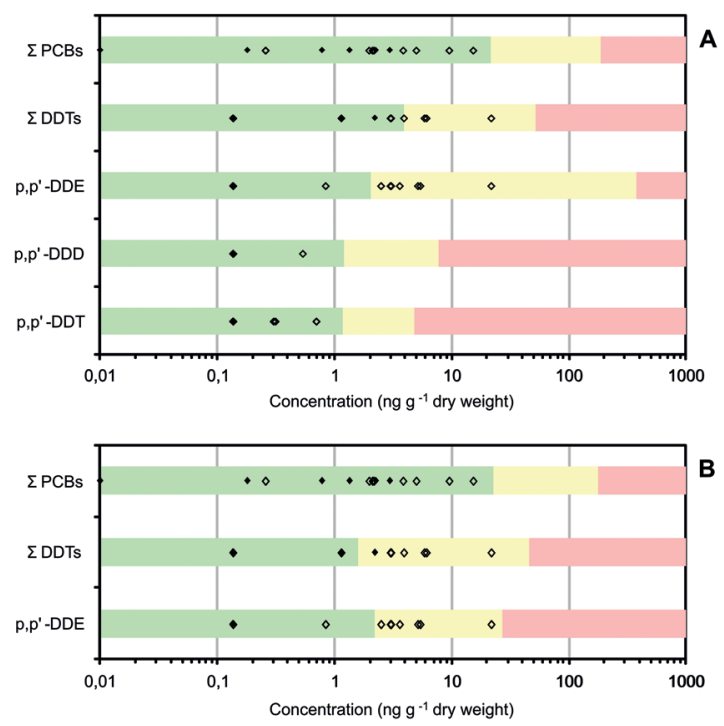

Figure 6. Comparison between concentration (ng g ${ }^{-1}$ dry weight) of persistent organic pollutants at sampling sites and the sediment quality guidelines proposed by (a) MacDonald et al. (1996) and (b) Long et al. (1995). Concentrations below MDL were plotted as one-half of it. Open and closed diamonds represent sediment samples collected from Pina Sound and Suape Estuary, respectively. Green, yellow and red areas represent the concentration ranges that are expected to be rarely, occasionally and frequently associated with adverse biological effects, respectively.

DDTs at Pina Sound and Suape Estuary is similar to levels found in coastal environments around the world, including other areas of Brazil. Nonetheless, contamination is at least one order of magnitude lower than at sites located in areas that witnessed heavy historical use of DDT such as India. In terms of sediment toxicity, DDTs may occasionally have adverse biological effects on the benthic organisms of Pina Sound. However, such effects are not expected to occur in Suape Estuary.

\section{ACKNOWLEDGEMENTS}

The authors thank Mr. Rafael Lemos for the extraction and clean up of samples in the laboratory. We also thank Dr. Roberto Barcellos for his assistance in the grain size analysis. Field trips were funded by $\mathrm{CNPq}$ (Grant No. 478589/2010-7) and FACEPE (Grant No. APQ-10111.08/10). Transpetro deserves credit for providing assistance with vessel and staff during the field trip on Suape Estuary. RC Montone is recipient of a research productivity fellowship from CNPq (Grant No. 307898/2014-8). The authors also thank Fundação de Amparo à Ciência e Tecnologia de Pernambuco (FACEPE/FAPESP Grant No. APQ-0074-1.08/11) for financial support and Fundação 
de Amparo à Pesquisa do Estado de São Paulo (FAPESP/ FACEPE/ANR Grant No. 2011/50582-0) for the cooperation activities developed in scope of the thematic project.

\section{REFERENCES}

AISLABIE, J. M., RICHARDS, N. K., \& BOUL, H. L. 1997. Microbial degradation of DDT and its residues - a review. New Zealand Journal of Agricultural Research, 40, 269-282.

ALMEIDA, F. V., CENTENO, A. J., BISINOTI, M. C. \& JARDIM, W. F. 2007. Substâncias tóxicas persistentes (STP) no Brasil. Química Nova, 30, 1976-1985.

ANZOLIN, D. G., SARKIS, J. E. S., DIAZ, E., SOARES, D. G., SERRANO, I. L., BORGES, J. C. G., SOUTO, A. S., TANIGUCHI, S., MONTONE, R. C., BAINY, A. C. D. \& CARVALHO, P. S. M. 2012. Contaminant concentrations, biochemical and hematological biomarkers in blood of West Indian manatees Trichechus manatus from Brazil. Marine Pollution Bulletin, 64, 1402-1408.

ARAÚJO, A. C. P., AUGUSTO, L. G. S. \& TELLES, D. L. 2000. A questão dos praguicidas na agricultura e a situação no Estado de Pernambuco. Revista Brasileira de Toxicologia, 13, 25-30.

ARIAS, A. H., PEREYRA, M. T. \& MARCOVECCHIO, J. E. 2011. Multi-year monitoring of estuarine sediments as ultimate sink for DDT, $\mathrm{HCH}$, and other organochlorinated pesticides in Argentina. Environmental Monitoring and Assessment, 172, 17-32.

ARIAS, A. H., VAZQUEZ-BOTELLO, A., DIAZ, G. \& MARCOVECCHIO, J. E. 2013. Accumulation of polychlorinated biphenyls (PCBs) in navigation channels, harbors and industrial areas of the Bahia Blanca estuary, Argentina. International Journal Of Environmental Research, 7, 925-936.

BARAKAT, A. O., MOSTAFA, A., WADE, T. L., SWEET, S. T. \& EL SAYED, N. B. 2013. Distribution and ecological risk of organochlorine pesticides and polychlorinated biphenyls in sediments from the Mediterranean coastal environment of Egypt. Chemosphere, 93, 545-554.

BARBOSA, C. C. A., SILVA, H. A., SÁ, L. A. C. M. \& PORTUGAL, J. L. 2008. Base de dados espaciais aplicada a erosão costeira. In: Anais do II Simpósio Brasileiro de Ciências Geodésicas e Tecnologias da Geoinformação. Recife: Universidade Federal de Pernambuco.

BAUER, J. E., CAI, W. J., RAYMOND, P. A., BIANCHI, T. S., HOPKINSON, C. S. \& REGNIER, P. A. G. 2013. The changing carbon cycle of the coastal ocean. Nature, 504, 61-70.

BHATTACHARYA, B., SARKAR, S. K. \& MUKHERJEE, N. 2003. Organochlorine pesticide residues in sediments of a tropical mangrove estuary, India: implications for monitoring. Environment International, 29, 587-592.

BÍCEGO, M. C., TANIGUCHI, S., YOGUI, G. T., MONTONE, R. C., SILVA, D. A. M., LOURENÇO, R. A., MARTINS, C. C., SASAKI, S. T., PELliZARI, V. H. \& WEBER, R. R. 2006. Assessment of contamination by polychlorinated biphenyls and aliphatic and aromatic hydrocarbons in sediments of the Santos and São Vicente Estuary System, São Paulo, Brazil. Marine Pollution Bulletin, 52, 1804-1816.

BIRCH, G. F. \& TAYLOR, S. E. 2000. Distribution and possible sources of organochlorine residues in sediments of a large urban estuary, Port Jackson, Sydney. Australian Journal of Earth Sciences, 47, 749-756.
BURGGRAAF, S., LANGDON, A. G. \& WILKINS, A. L. 1994. Organochlorine contaminants in sediments of the Tauranga Harbor, New Zealand. New Zealand Journal of Marine and Freshwater Research, 28, 291-298.

CAMARGO, M. G. 2006. SysGran: um sistema de código aberto para análises granulométricas do sedimento. Revista Brasileira de Geociências, 36, 371-378.

CANUEL, E. A., CAMMER, S. S., MCINTOSH, H. A. \& PONDELL, C. R. 2012. Climate change impacts on the organic carbon cycle at the land-ocean interface. Annual Review of Earth and Planetary Sciences, 40, 685-711.

CARVALHO, P. N., RODRIGUES, P. N. R., BASTO, M. C. P. \& VASCONCELOS, M. T. S. D. 2009. Organochlorine pesticides levels in Portuguese coastal areas. Chemosphere, 75, 595-600.

CIAIS, P., SABINE, C., BALA, G., BOPP, L., BROVKIN, V., CANADELL, J., CHHABRA, A., DEFRIES, R., GALLOWAY, J., HEIMANN, M., JONES, C., LE QUÉRÉ, C., MYNENI, R. B., PIAO, S. \& THORNTON, P. 2013. Carbon and other biogeochemical cycles. In: STOCKER, T. F., QIN, D., PLATTNER, G. K., TIGNOR, M., ALLEN, S. K., BOSCHUNG, J., NAUELS, A., XIA, Y., BEX, V. \& MIDGLEY, P. M. (eds.) Climate Change 2013: The Physical Science Basis. Contribution of the Working Group I to the Fifth Assessment Report of the Intergovernmental Panel on Climate Change. Cambridge: Cambridge University Press.

COMBI, T., TANIGUCHI, S., FIGUEIRA, R. C. L., MAHIQUES, M. M. \& MARTINS, C. C. 2013. Spatial distribution and historical input of polychlorinated biphenyls (PCBs) and organochlorine pesticides (OCPs) in sediments from a subtropical estuary (Guaratuba Bay, SW Atlantic). Marine Pollution Bulletin, 70, 247-252.

DUAN, X., LI, Y., LI, X., LI, M. \& ZHANG, D. 2013. Distributions and sources of polychlorinated biphenyls in the coastal East China Sea sediments. Science of the total environment, 463-464, 894-903.

EL NEMR, A., MONEER, A. A., KHALED, A. \& EL-SIKAILY, A. 2013. Levels, distribution, and risk assessment of organochlorines in surficial sediments of the Red Sea coast, Egypt. Environmental Monitoring and Assessment, 185, 4835-4853.

ESKENAZI, B., CHEVRIER, J., ROSAS, L. G., ANDERSON, H. A., BORNMAN, M. S., BOUWMAN, H., CHEN, A. M., COHN, B. A., JAGER, C., HENSHEL, D. S., LEIPZIG, F., LEIPZIG, J. S., LORENZ, E. C., SNEDEKER, S. M. \& STAPLETON, D. 2009. The Pine River statement: human health consequences of DDT use. Environmental Health Perspectives, 117, 1359-1367.

FARRAPEIRA, C. M. R. 2006. Barnacles (Cirripedia Balanomorpha) of the estuarine region of Recife, Pernambuco, Brazil. Tropical Oceanography, 34, 100-119.

FILLMANN, G., HERMANNS, L., FILEMAN, T. W. \& READMAN, J. W. 2007. Accumulation patterns of organochlorines in juveniles of Arctocephalus australis found stranded along the coast of Southern Brazil. Environmental Pollution, 146, 262-267.

FLORES MONTES, M. J., PAULO, J. G., NASCIMENTO FILHO, G. A., GASPAR, F. L., FEITOSA, F. A., SANTOS JUNIOR, A. C., BATISTA, T. N. F., TRAVASSOS, R. K. \& PITANGA, M. E. 2011. The trophic status of an urban estuarine complex in Northeast Brazil. Journal of Coastal Research, 64, 408-411.

GAMA, A. F., OLIVEIRA, A. H. B. \& CAVALCANTE, R. M. 2013. Inventory of pesticides and risk of chemical contamination of hydric resources in the semiarid cearense. Química Nova, 36, 462-467. 
GÓMEZ, S., GORRI, D. \& IRABIEN, A. 2011. Organochlorine pesticide residues in sediments from coastal environment of Cantabria (northern Spain) and evaluation of the Atlantic Ocean. Environmental Monitoring and Assessment, 176, 385-401.

HAMMER, O., HARPER, D. A. T. \& RYAN, P. D. 2001. PAST: paleontological statistics software package for education and data analysis. Palaeontologia Electronica, 4, 1-9.

HONG, H. S., CHEN, W., XU, L., WANG, X. \& ZHANG, L. 1999. Distribution and fate of organochlorine pollutants in the Pearl River estuary. Marine Pollution Bulletin, 39, 376-382.

IBGE (Instituto Brasileiro de Geografia e Estatística) 2016. Ministério do Planejamento, Orçamento e Gestão. Fundação Instituto Brasileiro de Geografia e Estatística. Estimativas da população para Estados e Municipios, com data de referência em $1^{\circ}$ de julho de 2015. Publicado no Diário Oficial da União (Seção 1), N 167 (30/08/2016). Brasília, Diário Oficial.

KIM, Y. S., EUN, H., CHO, H. S., KIM, K. S., SAKAMOTO, T., WATANABE, E., BABA, K. \& KATASE, T. 2008. Organochlorine pesticides in the sediment core of Gwangyang Bay, South Korea. Archives of Environmental Contamination and Toxicology, 54, 386-394.

LEMOS, R. T. O., CARVALHO, P. S. M. \& ZANARDI-LAMARDO, E. 2014. Petroleum hydrocarbons in water from a Brazilian tropical estuary facing industrial and port development. Marine Pollution Bulletin, 82, 183-188.

LONG, E. R., MACDONALD, D. D., SMITH, S. L. \& CALDER, F. D. 1995. Incidence of adverse biological effects within ranges of chemical concentrations in marine and estuarine sediments. Environmental Management, 19, 81-97.

MACDONALD, D. D., CARR, R. S., CALDER, F. D., LONG, E. R. \& INGERSOLL, C. G. 1996. Development and evaluation of sediment quality guidelines for Florida coastal waters. Ecotoxicology, 5, 253-278.

MACIEL, D. C., SOUZA, J. R. B., TANIGUCHI, S., BÍCEGO, M. C. \& ZANARDI-LAMARDO, E. 2015. Sources and distribution of polycyclic aromatic hydrocarbons in an urbanized tropical estuary and adjacent shelf, Northeast of Brazil. Marine Pollution Bulletin, 101, 429-433.

MINH, N. H., MINH, T. B., IWATA, H., KAJIWARA, N., KUNISUE, T., TAKAHASHI, S., VIET, P. H., TUYEN, B. C. \& TANABE, S. 2007. Persistent organic pollutants in sediments from Sai Gon-Dong Nai River basin, Vietnam: levels and temporal trends. Archives of Environmental Contamination and Toxicology, 52, 458-465.

MIRANDA, D. A. \& YOGUI, G. T. 2016. Polychlorinated biphenyls and chlorinated pesticides in king mackerel caught off the coast of Pernambuco, northeastern Brazil: Occurrence, contaminant profile, biological parameters and human intake. Science of the Total Environment, 569-570, 1510-1516.

MMA - Ministry of Environment in Brazil. 2006. Development of a National Implementation Plan in Brazil as a First Step to Implement the Stockholm Convention on Persistent Organic Pollutants (POPs). Brasília, Ministry of Environment.

MORAES, A. C. R. 2007. Contribuições para a Gestão da Zona Costeira do Brasil: Elementos para uma Geografia do Litoral Brasileiro, São Paulo, Annablume.

NASCIMENTO, F. C. R., MUNIZ, K., FEITOSA, F. A. N., ARAÚJO, J. P., SILVA, R. M. S., SILVA, G. S. \& FLORES MONTES, M. J. 2003. Disponibilidade nutricional da Bacia do Pina e Rio Tejipió (Recife - PE - Brasil) em relação aos nutrientes e biomassa primária (setembro/2000). Tropical Oceanography, 31,149-169.
NASCIMENTO, N. R., NICOLA, S. M. C., REZENDE, M. O. O., OLIVEIRA, T. A. \& ÖBERG, G. 2004. Pollution by hexachlorobenzene and pentachlorophenol in the coastal plain of São Paulo state, Brazil. Geoderma, 121, 221-232.

NOUIRA, T., RISSO, C., LASSAAD, C., BUDZINSKI, H. \& BOUSSETTA, H. 2013. Polychlorinated biphenyls (PCBs) and polybrominated diphenyl ethers (PBDEs) in surface sediments from Monastir Bay (Tunisia, central Mediterranean): occurrence, distribution and seasonal variations. Chemosphere, 93, 487-493.

OLIVEIRA, A. H. B., CAVALCANTE, R. M., DUAVI, W. C., FERNANDES, G. M., NASCIMENTO, R. F., QUEIROZ, M. \& MENDONÇA, K. V. 2016. The legacy of organochlorine pesticide usage in a tropical semi-arid region (Jaguaribe River, Ceará, Brazil): implications of the influence of sediment parameters on occurrence, distribution and fate. Science of The Total Environment, 542, 254-263.

PARANAGUÁ, M. N., NEUMANN-LEITÃO, S., NOGUEIRA-PARANHOS, J. D., SILVA, T. A. \& MATSUMURA-TUNDISI, T. 2005. Cladocerans (Branchiopoda) of a tropical estuary in Brazil. Brazilian Journal of Biology, 65, 107-115.

PENTEADO, J. C. P. \& VAZ, J. M. 2001. O legado das bifenilas policloradas (PCBs). Química Nova, 24, 390-398.

QIU, X., ZHU, T., YAO, B., HU, J. \& HU, S. 2005. Contribution of dicofol to the current DDT pollution in China. Environmental Science \& Technology, 39, 4385-4390.

SCHETTINI, C. A. F., MIRANDA, J. B., VALLE-LEVINSON, A., TRUCCOLO, E. C., \& DOMINGUES, E. C. 2016. The circulation of the lower Capibaribe estuary (Brazil) and its implications for the transport of scalars. Brazilian Journal of Oceanography, 64, 263-275.

SERICANO, J. L., WADE, T. L., JACKSON, T. J., BROOKS, J. M., TRIPP, B. W., FARRINGTON, J. W., MEE, L. D., READMANN, J. W., VILLENEUVE, J. P. \& GOLDBERG, E. D. 1995. Trace organic contamination in the Americas: An overview of the US National Status \& Trends and the International 'Mussel Watch' programmes. Marine Pollution Bulletin, 31, 214-225.

SERICANO, J. L., WADE, T. L., SWEET, S. T., RAMIREZ, J. \& LAUENSTEIN, G. G. 2014. Temporal trends and spatial distribution of DDT in bivalves from the coastal marine environments of the continental United States, 1986-2009. Marine Pollution Bulletin, 81, 303-316.

SHEPARD, F. P. 1954. Nomenclature based on sand-silt-clay ratios. Journal of Sedimentary Research, 24, 151-158.

SOUZA, A. S., TORRES, J. P. M., MEIRE, R. O., NEVES, R. C., COURI, M. S. \& SEREJO, C. S. 2008. Organochlorine pesticides (OCs) and polychlorinated biphenyls (PCBs) in sediments and crabs (Chasmagnathus granulata, Dana, 1851) from mangroves of Guanabara Bay, Rio de Janeiro State, Brazil. Chemosphere, 73, S186-S192.

SOUZA, D. S. M., RAMOS, A. P. D., NUNES, F. F., MORESCO, V., TANIGUCHI, S., LEAL, D. A. G., SASAKI, S. T., BICEGO, M. C., MONTONE, R. C., DURIGAN, M., TEIXEIRA, A. L., PILOTTO, M. R., DELFINO, N., FRANCO, R. M. B., MELO, C. M. R., BAINY, A. C. D. \& BARARDI, C. R. M. 2012. Evaluation of tropical water sources and mollusks in southern Brazil using microbiological, biochemical, and chemical parameters. Ecotoxicology and Environmental Safety, 76, 153-161.

SUGUIO, K. 1973. Introdução à Sedimentologia, São Paulo, Blücher. 
TANABE, S., SUBRAMANIAN, A., RAMESH, A., KUMARAN, P. L., MIYAZAKI, N. \& TATSUKAWA, R. 1993. Persistent organochlorine residues in dolphins from the Bay of Bengal, south India. Marine Pollution Bulletin, 26, 311-316.

TOLOSA, I., MESA-ALBERNAS, M. \& ALONSO-HERNANDEZ, C. M. 2010. Organochlorine contamination (PCBs, DDTs, HCB, HCHs) in sediments from Cienfuegos Bay, Cuba. Marine Pollution Bulletin, 60, 1619-1624.

UNEP (United Nations Environment Programme). 1992. Determination of Petroleum Hydrocarbons in Sediments. Reference Methods for Marine Pollution Studies No. 20. Nairobi: United Nations Environment Programme.

VAN AEL, E., COVACI, A., BLUST, R. \& BERVOETS, L. 2012. Persistent organic pollutants in the Scheldt estuary: environmental distribution and bioaccumulation. Environment International, 48, 17-27.

WADE, T. L. \& CANTILLO, A. Y. 1994. Use of Standards and Reference Materials in the Measurement of Chlorinated Hydrocarbon Residues. Chemistry Workbook. NOAA Technical Memorandum NOS ORCA 77. Silver Spring: Department of Commerce.
WHO (World Health Organization). 1989. DDT and its derivatives: environmental aspects / published under the joint sponsorship of the United Nations Environment Programme, the International Labour Organisation, and the World Health Organization. Geneva: World Health Organization.

WHO (World Health Organization) 2011. The Use of DDT in Malaria Vector Control: WHO Position Statement. Global Malaria Programme. Geneva: World Health Organization.

Yogui, G. T., SANTOS, M. C. O., BeRTOZZI, C. P. \& MONTONE, R. C. 2010. Levels of persistent organic pollutants and residual pattern of DDTs in small cetaceans from the coast of São Paulo, Brazil. Marine Pollution Bulletin, 60, 1862-1867.

YOGUI, G. T., SANTOS, M. C. O. \& MONTONE, R. C. 2003. Chlorinated pesticides and polychlorinated biphenyls in marine tucuxi dolphins (Sotalia fluviatilis) from the Cananéia estuary, southeastern Brazil. Science of The Total Environment, $312,67-78$. 